\title{
PENDAMPINGAN PEMBUATAN MURAL SEBAGAI UPAYA MENINGKATKAN EDUKASI BELAJAR SERTA PERBAIKAN VISUAL SEKOLAH
}

\author{
Zhilli Izzadati Khairuni, Rumilla Harahap, Kemala Jeumpa \\ Universitas Negeri Medan
}

Zhilli_ft@unimmed.ac.id, rumi_harahap@yahoo.com, ipajeumpa@gmail.com

\begin{abstract}
Abstrak
Target kegiatan pengabdian adalah sebuah sekolah yang terletak dipinggiran Kota Medan tepatnya Perumnas Simalingkar Medan Tuntungan. Sekolah ini merupakan sekolah yang memiliki visi misi membantu masyarakat sekitar agar dapat sekolah dengan biaya murah bahkan gratis pada kondisi keluarga tertentu. Beberapa tahun terakhir terjadi penurunan siswa yang berminat untuk mendaftar pada sekolah tersebut. Kondisi ini menyebabkan biaya operasional sekolah untuk perawatan bangunan perlahan-lahan tidak teralokasikan lagi. Hal ini yang membuat tim PKM berencana untuk memberikan wawasan terkait fisik bangunan sesuai dengan bidang ilmu teknik dan seni. Salah satu upaya yang dapat dilakukan untuk mewujudkan visual yang baik dan menarik adalah memperbaiki fisik bangunan. Upaya tersebut berupa aplikasi seni mural, selain dianggap memperindah tampilan fisik bangunan, seni mural ini juga dapat memperkuat karakter sebuah kawasan. Metode yang dilakukan adalah dengan metode sosialisasi, membuat konsep desain, kemudian praktik dengan bimbingan pembuatan mural, serta monitoring dan evaluasi. Dalam kegiatan ini tahap-tahap yang lakukan adalah memberi materi pendahuluan berupa pemahaman arsitektur, tahap persiapan pembuatan desain mural dan tahap mengecat. Mural yang dihasilkan dalam bentuk mural edukasi dengan beberapa ragam pengetahuan. Hasil kegiatan ini diharapkan adanya peningkatan ekonomi, peningkatan ilmu seni bagi mitra terpilih sekaligus memperbaiki visual bangunan sekolah.
\end{abstract}

Kata kunci : visual, mural, edukasi, sekolah, seni.

\section{PENDAHULUAN}

Yayasan perguruan Ar-ridha adalah salah satu sekolah islam yang berada di Perumnas Simalingkar Kecamatan Medan Tuntungan Kabupaten Deli Serdang Kota Medan. Berdiri pada tahun 2000, di jalan karet raya no 68 AA Perumnas Simalingkar. Sekolah ini sempat menjadi pilihan masyarakat setempat dikarenakan lokasi yang strategis dan kualitas guru-guru yang baik. Perkembangan dunia pendidikan yang semakin meningkat menyebabkan banyak sekolah-sekolah swasta bermunculan. Hal ini menjadi salah satu pertimbangan orang tua dalam memilih sekolah, salah satunya fasilitas. Jika diamati beberapa gedung sekolah mulai kurang perawatan, sehingga kegiatan belajar para murid menjadi terganggu seperti kondisi cat yang terkelupas atau lantai yang pecah-pecah (Wahyudi et al., 2017). Sekolah yang menjadi objek pengabdian berada dipinngar jalan besar, sehingga memudahkan akses kendaraan, terjangkau oleh kendaraan yang lalu lalang akan tetapi kurang Teknologi Informasi dan Komunikasi 
menarik untuk dilihat. Berikut ini adalah tampilan sekolah berdasarkan pengamatan sementara. Tampilan arsitektur fasade bangunan pada sebuah kawasan memiliki peran penting untuk membangun karakter visual kawasan yang dapat menggambarkan citra kawasan itu sendiri. Sebuah karakter akan memudahkan orang untuk mengenali kawasan tersebut. (Harani \& Motic, 2017)

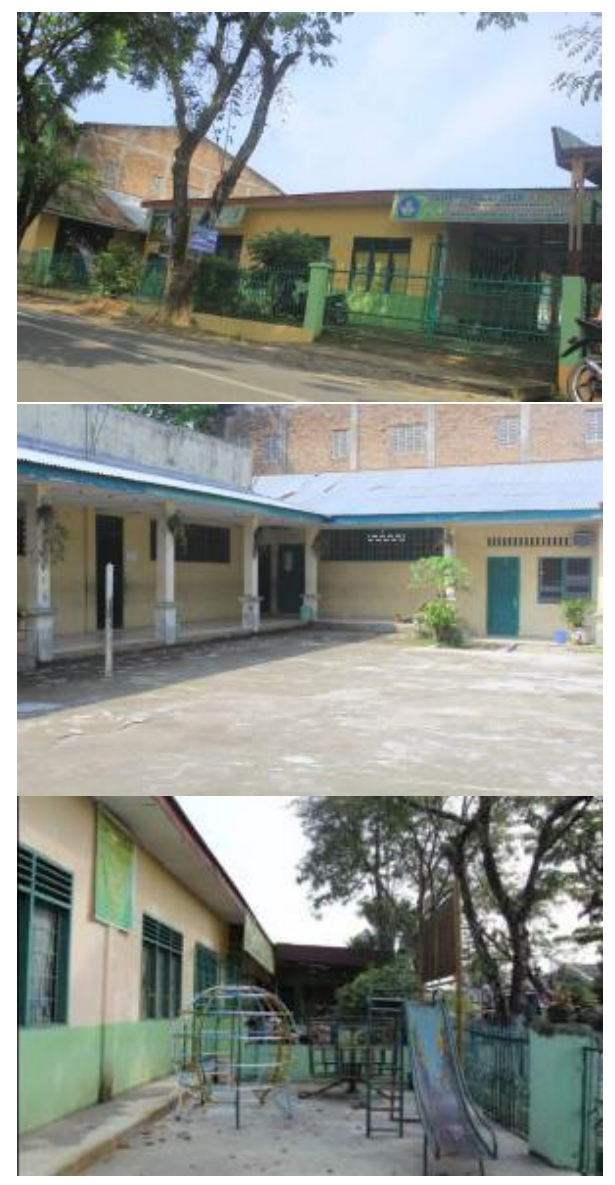

Gambar 1 (Kondisi sekolah sebagai mitra PKM) Sumber: Dokumentasi Pribadi

Gambar sekolah ini memperlihatkan lokasi sekolah yang berapa di pinggir jalan besar. Sekolah ini memiliki halaman yang luas sebagai area bermain dan juga memiliki lapangan upacara yang digunakan sebagai lapangan olahraga. Jika dilihat dari kelengkapan fasilitas sebuah sekolah seperti lapangan, area bermain, mushalla dan sebagainya. Maka sekolah ini termasuk sekolah yang memenuhi syarat fasilitas yang baik, hanya saja perawatan yang kurang disiplin oleh pengelola/pengurus sekolah tersebut.

Lokasi yang dipilih adalah sebuah sekolah dengan tingkat penurunan siswa yang terjadi dari tahun ke tahun, hal ini menyebabkan penurunan kualitas dan kuantitas management sekolah dalam pengelolaan biaya internal, sehingga biaya operasional untuk perawatan sekolah tidak dapat dialokasikan. Jika hal ini dibiarkan maka dapat dipredikasi sekolah akan ditutup. Dari hasil analisa sementara pengusul melihat kondisi sekolah yang sudah mulai tidak terawat dan ingin memberikan solusi untuk menampilkan wajah baru sekolah dengan konsep seni/art yang dituangkan dalam bentuk mural edukasi. Selain memperbaiki visual pada sekolah diharapkan mural tersebut dapat bermanfaat bagi guru dan siswa untuk menambah minat belajar. Dalam suatu program pengembangan dan pembangunan lingkungan, peran serta masyarakat dituntut lebih aktif dan adanya kesadaran rasa memiliki. Masyarakat berhak dan berperan dalam pengambilan keputusan, pelaksanaan, pengawasan, evaluasi, dan sampai akhirnya masyarakatlah yang berhak menikmati hasil dan manfaatnya. Inilah yang dimaksud dengan partisipasi masyarakat dalam pembangunan lingkungannya. (Yusuf, 2014).

Hasil analisa situasi yang telah dijabarkan, diketahui bahwa permasalahan yang ada di sekolah ini sebagai berikut : 1) Keberadaan sekolah yang pernah memiliki masa kejayaannya perlahan-lahan sirna dengan banyaknya bermunculan sekolahsekolah swasta lain yang lebih menarik secara tampilan fisik. 2) Pengelola/pengurus sekolah belum memiliki ide khusus untuk memperindah tampilan fisik bangunan, dan perawatan sebatas mengecat bangunan setiap tahunnya. Ditambah lagi dengan meredupkan perekonomian sekolah tersebut yng menyebabkan terbatasnya biaya operasional untuk perawatan gedung.3) Kondisi sekolah yang minim edukasi seperti taman bermain yang mencangkup pada konsep visual, audio dan kinestetik.

Solusi permasalahan mitra yang menjadi prioritas pengusul PKM adalah sebagai berikut : 1) Membuat sebuah survey ke beberapa sekolah (max.2-3 sekolah) yang berada berdekatan untuk mengetahui kondisi penurunan minat masyarakat

Teknologi Informasi dan Komunikasi 
terhadap sekolah yang menjadi target pengabdian. 2) Memberi pemahaman dan membuka wawasan kepada pengelola/pengurus sekolah mengenai pentingnya tampilan fisik bangunan terhadap penilaian orang tua dalam memilih sekolah anak. Dengan pemahaman tersebut dapat meningkatkan ekonomi sekolah.3) Memberi pemahaman dan wawasan bagi pengelola, guru-guru terhadap edukasi untuk meningkatkan kemampuan anak melalui visual, audio dan kinesteti yang bisa diberikan diluar kelas agar guru dan siswa dapat berinteraksi dengan baik.

\section{METODE}

Setelah memperoleh data dan informasi yang akurat dari permasalahan yang dialami oleh sekolah yang menjadi target pengabdian. Selanjutnya dasar tersebut dijadikan dasar bagi tim untuk mencari solusi yang paling tepat yang nantinya akan digunakan untuk memecahkan masalah yang akan dihadapi. Setelah melakukan analisis maka tim memutuskan solusi yang digunakan yaitu memberikan sosialisasi dan pendampingan yang berkaitan dengan bidang ilmu arsitektur. Adapun metode yang akan dilakukan dalam kegiatan pengabdian masyarakat ini adalah sebagai berikut.1) Metode Ceramah atau presentasi berkaitan dengan pengenalan konsep mural. Bahan ceramah (presentasi) diberikan pada peserta. Setelah selesai ceramah dilanjutkan dengan diskusi (tanya jawab) dan praktek langsung di lapangan. 2) Metode Demonstrasi meliputi pengenalan langkah-langkah pembuatan mural serta berbagai tema desain yang dapat diterapkan. 3) Metode Praktik meliputi pendampingan pembuatan mural pada dinding yang telah ditentukan sebagai upaya perbaikan visual sekolah dengan bimbingan pelaksana kegiatan dan mitra mural. Praktek secara langsung juga merupakan metode yang digunakan dalam penyampaian materi dengan memberikan gambarangambaran seni/art pada fisik bangunan dan praktek aplikasi seni/art dalam bentuk mural di perlihatkan langsung kepada guru dan pengelola sekolah yang mengikuti pelatihan ini. (Thamrin \& Noviana, 2020). 4) Metode Tanya jawab dan diskusi antara tim PKM dan peserta. 5) Metode evaluasi berupa umpan balik dari peserta pengabdian masyarakat, yaitu pengelola dan guru-guru sekolah.

\section{HASIL DAN PEMBAHASAN}

\section{Pembahasan}

Mural dan Perkembangannya

Mural merupakan sebuah lukisan yang besar pada sebuah dinding, namun mural tidak sama dengan karya lukis. Terdapat syarat khusus sebuah karya dapat dikatakan sebagai sebuah karya mural, yaitu kaitannya dengan arsitektur/bangunan, baik dari sisi desain (mempunyai unsur estetika), maupun usia serta perawatannya dan juga dari sisi kenyamanan dalam pengamatannya. Mural dapat diproduksi baik di dalam maupun luar ruangan.

Sejarah mencatat bahwa mural sudah ada sejak jaman prasejarah, yaitu 31.500 tahun silam, yang terdapat di lukisan gua di Lascaux, di selatan Perancis. Di Indonesia sendiri tercatat bahwa lukisan dinding juga sudah ada sejak jaman prasejarah, yaitu di jaman Mesolitikum. Pada saat itu lukisan dinding digunakan sebagai tanda bahwa pernah ada manusia yang telah menghuni dan melangsungkan kehidupan di gua tersebut.

Sejarah seni rupa juga mencatat, lukisan mural yang terkenal adalah Guernica atau Guernica y Luno karya Pablo Picasso, yang dibuat saat perang sipil Spanyol di tahun 1937. Mural ini dibuat dalam rangka memperingati pengeboman tentara Jerman di sebuah desa kecil. Sementara di Indonesia sendiri juga tercatat bahwa ketika perang untuk meraih kemerdekaan, banyak para pahlawan dan masyarakat menggunakan media mural untuk mengobarkan semangat dalam meraih kemerdekaan. (Nababan, 2019).

Salah satu upaya yang dapat dilakukan untuk memperbaiki kualitas visual sebuah kawasan adalah dengan seni mural. Selain dianggap memperindah tampilan kawasan, keberadaan gambar-gambar dan warna ini juga dapat memperkuat karakter sebuah kawasan. Oelh sebab itu, keberadaan bangunan sebagai media mural berupa dinding sangat diperlukan. Dinding tidak hanya berfungsi sebagai pembatas ruang namun juga dapat digunakan sebagai media untuk memperindah ruangan. Mural juga dapat dijadikan sebagai petanda atau penanda identitas suatu tempat. (Ramadani \& Sabiruddin, 2018) 
Manfaat dalam menggunakan seni mural, sebagai berikut: 1) Meningkatkan Kreativitas. Bukan hanya membuat ruang tampak indah, namun juga memberi nilai lebih pada ruangan tersebut. Dapat merangsang daya seni dan imajinasi pada orang yang melihatnya. 2) Memberi Kesan dinding yang luas. Melalui gambar, pola dan warna tertentu yang ditampilkan oleh lukisan mural di dinding, dapat membuat dinding rumah terkesan lebih luas dan lapang. 3) Media Edukasi. Sering kali lukisan mural juga digunakan sebagai sarana edukasi. Misalnya dengan memberi penyuluhan untuk melakukan sesuatu, baik secara langsung maupun tidak langsung.

Beberapa teknik dalam mebuat seni mural sebagai berikut: 1) Teknik Proyektor. Cara melukisnya ialah dengan memanfaatkan gambar yang keluar dari proyektor dan melukisnya. Dengan hanya mengikuti bentuk bayangan dan mewarnainya, lukisan mural dapat diselesaikan. Untuk menggunakan teknik ini, juga harus memperhatikan pencahayaan yang ada dalam ruangan. Usahakan cahaya yang ada di buat seminim mungin, agar gambar yang keluar dari proyektor terlihat dengan jelas. 2) Teknik Kertas Karbon.Teknik kedua ini masih dapat dikategorikan sebagai teknik yang mudah, karena hanya cukup meniru gambar aslinya menggunakan kertas karbon, kertas transfer, atau kertas kopi. Teknik ini sangat direkomendasikan bagi pemula yang masih ragu untuk membuat mural dnegan goresan tangan sendiri. Tetapi, dalam menggunakan teknik ini juga harus berhati-hati karena kertas tidak boleh goyah sedikitpun.3) Teknik Skala. Dengan menggunakan perbandingan dalam skala tertentu agar gambar dapat diperbesar. Rancanglah terlebih dahulu konsep dinding kamar melalui software desain menggunakan skala yang tepat. Selanjtunya berikan garis-garis vertikal dan horizontl sebagai skalannya. Dan cetak hasil olahan desain tersebut. 4) Teknik Langsung. Teknik yang terakhir adalah teknik yang digunakan oleh pemural profeisonal dengan alasan menghemat waktu pengerjaan. Karena sudah terbiasa membuat mural, tidak ada kesulitan berarti saat membuat mural dengan konsep yang rumit sekalipun. Hasillnya, tentu saja terlihat indah dan tidak miring. Tetapi bagi yang merasa dirinya masih terbilang pemula, disarankan untuk menghindari teknik ini kalau tidak ingin membuang-buang waktu, biaya dan tenaga yang sudah dikeluarkan dengan percuma.

\section{Hasil Program}

Kegiatan Pengabdian kepada masyarakat dibuat untuk memberikan pemahaman kepada pengelola sekolah serta mendampingi dan memberi pelatihan dalam pembuatan mural. Kegiatan ini di awali dengan pemberian materi dalam sebuah sosialisasi mengenai pengetahuan umum mengenai teknik dan seni mural, potensi mural, serta fungsi mural sebagai unsur estetika yang dapat memperindah bangunan dan menjadikan lingkungan kawasan memiliki daya tarik yang berbeda. Selain memberikan pengetahuan sesuai pada materi yang telah dibagikan, tim pengabdian juga memberi motivasi kepada pengelola dan guru-guru untuk mempelajari pembuatan mural dan manfaat apa yang didapat dari kegiatan PKM ini. Partisipasi warga sekolah dalam kegiatan mural dilingkungan sekolah, menjadi salah satu media pengenalan warga sekolah terhadap peme-liharaan dan menjaga lingkungan menjadi lebih indah dan sehat (Chotib, 2012).

Pemahaman peserta dapat diukur dengan proses tanya jawab. Setelah metode ceramah perkenalan teori maka dilanjutkan dengan memperkenal alat dan bahan apa saja yang akan digunakan pada kegiatan ini. Alat dan bahan dipersiapkan oleh tim pengusul dan panitia pelaksana. Setelah itu dilanjutkan dengan pemberian penjelasan sekaligus mencontohkan proses pembuatan mural pada dinding yang telah ditentukan, dengan metode demonstrasi. Peserta pelatihan langsung praktik pembuatan mural yang didampingi oleh tim pelaksana. Pelaksanaan praktik ini tim pelaksana dibantu 5 orang mahasiswa Prodi Pendidikan Teknik Bangunan UNIMED, yang berperan sebagai asisten instruktur dan mahasiswa Jurusan Pendidkan Seni Rupa sebagai mitra pada kegiatan PKM. Tugas asisten instruktur adalah membimbing dan mendampingi peserta kegiatan dalam proses pembuatan mural, dan mitra sebagai pembuatan mural sehingga dalam pelaksanaannya lebih mudah dan lancar.

Kegiatan PKM ditujukan kepada pengelola dan guru-guru sekolah. Kegiatan dilakukan mulai

Teknologi Informasi dan Komunikasi 
dari bulan Juni 2020 survey awal lokasi, dan 14-18 Juli 2020 kegiatan sosialisasi dilokasi sekolah dan proses pembuatan mural dimulai pada 28 Juli 2020 sampai dengan 7 Agustus 2020 dilaksanakan di bangunan terdepan sekolah. Serah Terima dilakaksanakan pada 10 Agustus 2020 dan kegiatan umpan balik pada 28 Agustus 2020. Pelaksanaan kegiatan PKM pendampingan pembuatan mural ini terdiri dari beberapa tahap, yaitu sebagai berikut:

\section{Sosialisasi Kegiatan dan Diskusi Tema mural}

Kegiatan sosialisasi dalam bentuk memberikan pengetahuan umum mengenai mural dan bagaimana cara mengaplikasi mural, kegiatan ini juga disertai diskusi untuk mendapatkan kesepakatan dalam menentukan tema mural yang akan diterapkan di dinding sekolah. Kegiatan ini dijelaskan pada gambar 2
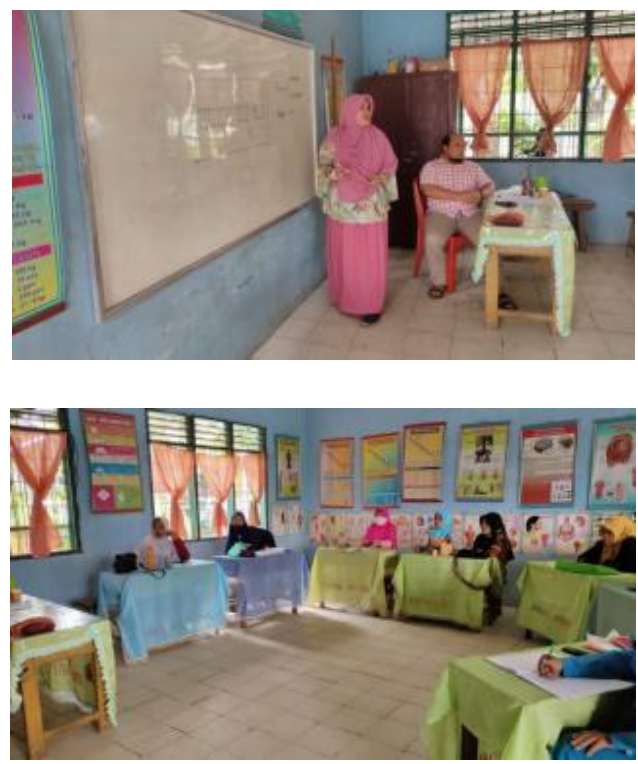

Gambar 2 (Kegiatan sosialisasi dan diskusi untuk menentukan tema mural)

Sumber. Dokumentasi Pribadi

\section{Pembuatan Sketsa Mural}

Setelah melakukan diskusi, tim PKM beserta mahasiswa membuat sketsa yang menggambarkan ide yang akan diterapkan di dinding sekolah. Tujuan dari sketsa ini untuk memberikan gambaran dari ideide peserta PKM yang telah dituangkan pada saat sosialisasi. Hasil dari sketsa ini tentunya tidak akan sama persis, dan akan menyesuaikan kondisi dinding pada sekolah, mulai dari penyesesuaian skala dan kondisi dinding yang tidak rata. Sketsa dibuat pada gambar 3.
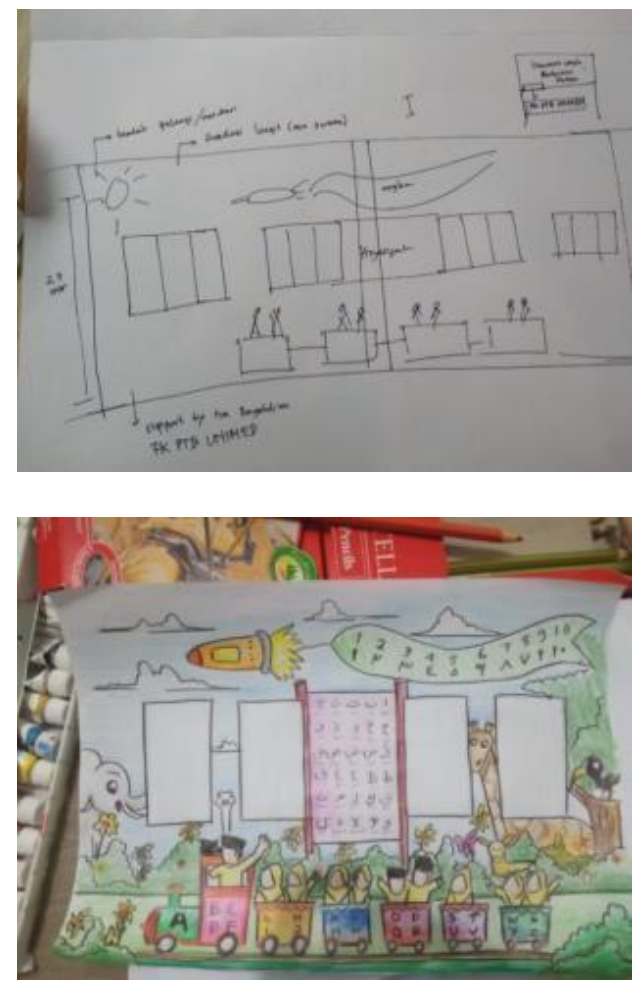

Gambar 3 (Sketsa Mural sebagai ide dasar dalam pembuatan konsep desain) Sumber: Dokumentasi Pribadi

Persiapan dinding yang akan di aplikasikan mural

Hal yang paling mendasar dalam membuat mural adalah kondisi dinding yang harus bersih, maka dilakukan teknik pengecatan dasar sebelum konsep dituangkan (Gambar 4). 

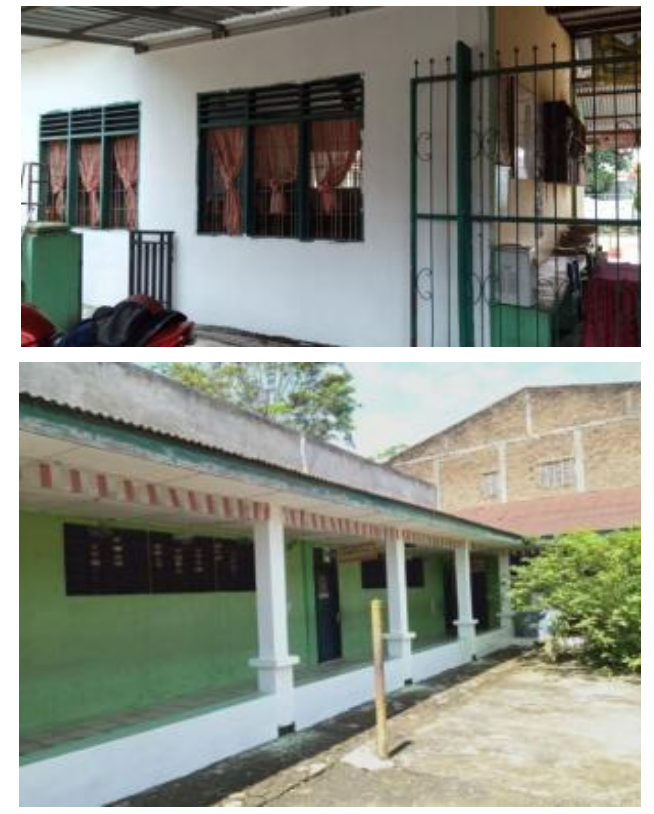

Gambar 4 (Proses Pengecatan Dasar dilakukan oleh Mahasiswa Teknik dan Seni Rupa)

Sumber: Dokumentasi Pribadi

\section{Proses Penggambaran}

Kegiatan ini telah melibatkan mahasiswa dari 2 fakultas yaitu mahasiswa teknik dan juga mahasiswa seni, untuk menyelaraskan lintas bidang ilmu serta membuat pengetahuan mahasiswa semakin kaya akan pengalaman. Berikut ini proses pemggambaran konsep pada dinding yang sudah di cat dasar (gambar 5)

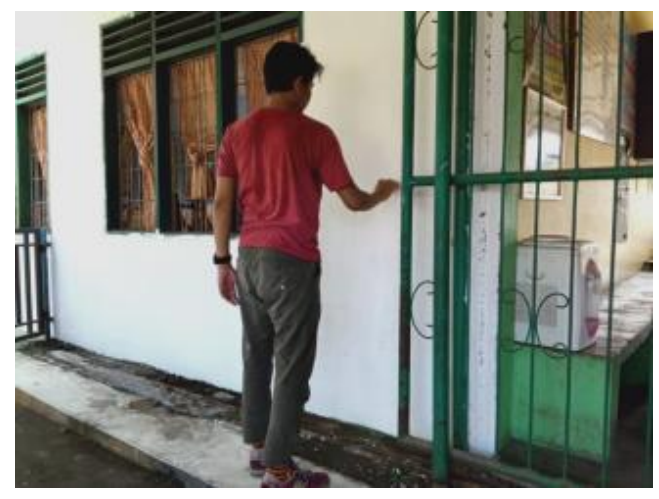

Gambar 5 (Proses Pengecatan Dasar dilakukan oleh Mahasiswa Teknik dan Seni Rupa) Sumber: Dokumentasi Pribadi

Proses pembuatan Mural dengan Tema Edukasi

Kegiatan ini sebagian besar telah dikerjakan oleh mahasiswa seni rupa sebagai mitra mural agar kualitas gambar terjaga komposisi dan tetap presisi. Tim pengabdian sebagai pengawas, memberikan arahan serta mendampingi guru-guru dalam mendapatkan informasi pembuatan mural. Bersamasama dengan guru, pengelola dan mahasiswa teknik serta mahasiswa senirupa telah transfer ilmu dalam proses penerapan warna-warna cat pada dinding. Kegiatan ini telah di rancang dengan timeline yang baik agar tidak terjadi kerusakan pada produk jika dikerjakan dalam waktu yang berjarak. Kegiatan ini di selesaikan dalam kurun waktu kurang lebih 2 minggu. Proses kegiatan ini di dokumentasikan pada gambar 6 berikut ini.
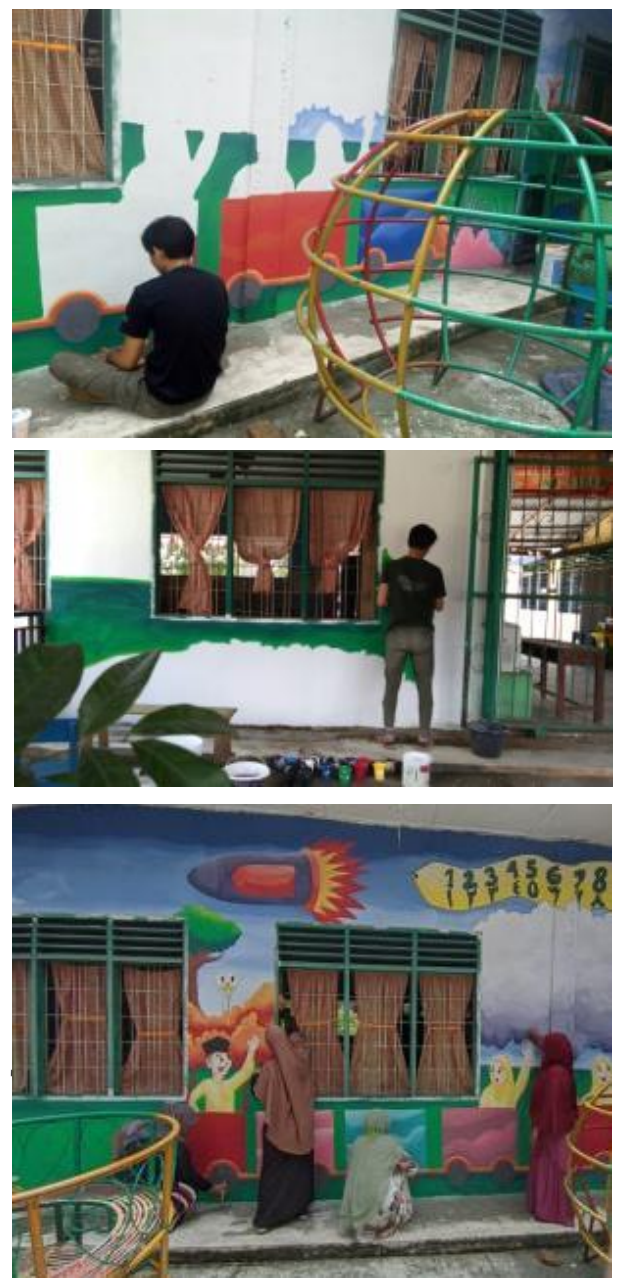
Gambar 6. (Kegiatan transfer ilmu kepada guruguru yang terlibat pada kegiatan PKM) Sumber: Dokumentasi Pribadi

\section{Kegiatan Pendampingan}

Kegiatan ini di dampingi oleh staff LPPM dan dosen pendamping lintas bidang ilmu dari prodi seni rupa untuk memastikan kegiatan benar dilakukan dan menghindari adanya kegiatan yang PKM yang tidak dilaksanakan sesuai arahan yang telah disepakati. (Gambar 7)

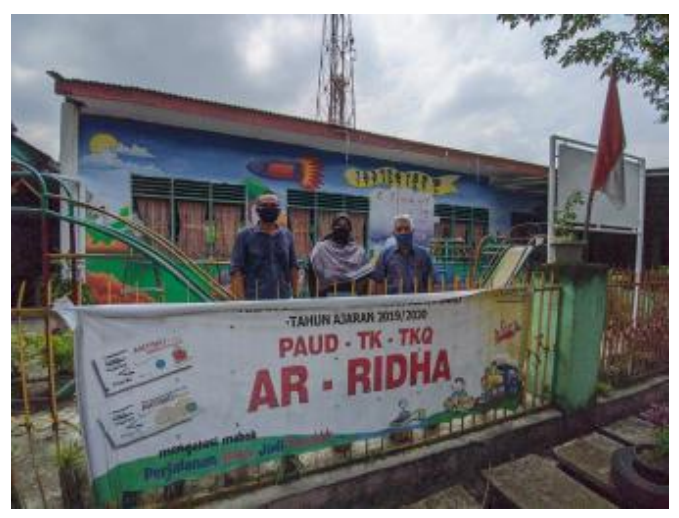

Gambar 7. (Pendampingan PKM oleh Staff LPPM dan Dosen Seni Rupa UNIMED) Sumber: Dokumentasi Pribadi

\section{Serah Terima Barang/Jasa}

Sebagai bentuk kegiatan ini telah terlaksana, tim PKM beserta mahasiswa dan guru-guru peserta PKM melakukan dokumentasi bersama (Gambar 8). Bukti dari kegaiatan ini juga dilakukan dalam penandatangan surat pernyataan serah terima barang oleh ketua tim PKM dan pengelola sekolah (Gambar 9)

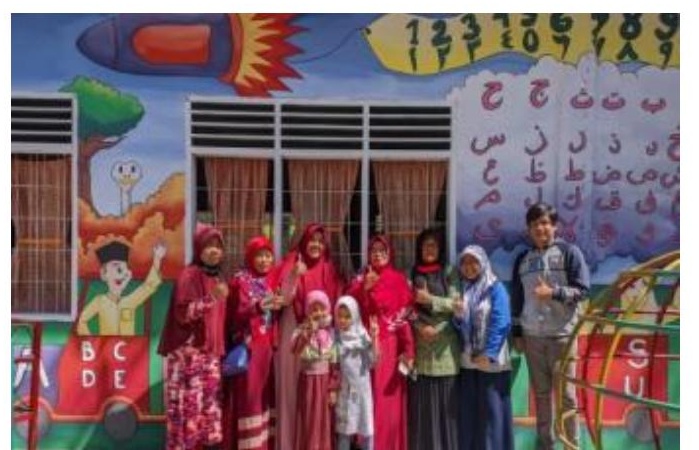

Gambar 8. (Foto bersama tim PKM, Mahasiswa dan Guru-guru peserta PKM) Sumber: Dokumentasi Pribadi
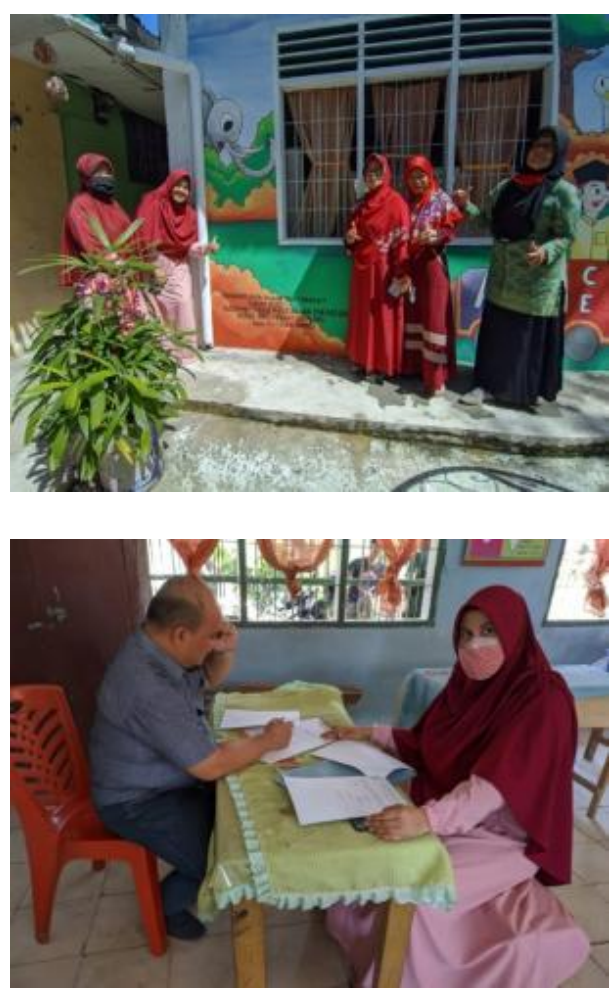

Gambar 9. (Tanda Tangan Surat Berita Acara Serah Terima Barang dengan Pengelola Sekolah) Sumber: Dokumentasi Pribadi

Evaluasi Kegiatan Pengabdian

Sebagai evaluasi pelaksanaan kegiatan pengabdian masyarakat pembuatan mural edukasi ini, tim pengabibdian melakukan umpan balik. Kegiatan umpan balik dilakukan oleh peserta kegiatan dengan mengisi kuisioner yang berisikan 5 pertanyaan pilihan ganda dan 1 pertanyaan. Pertanyaan-pertanyaan yang diberikan berupa hal apa saja yang di peroleh peserta pengabdian pada Teknologi Informasi dan Komunikasi 
kegiatan pembuatan mural edukasi ini. Jawaban berupa pilihan kepuasan para peserta dalam mengikuti kegiatan ini. 10 orang responden yang mengisi survey terdiri dari pengelola sekolah, guruguru dan mahasiswa yang terlibat pada kegiatan pengabdian pembuatan mural edukasi. Hasil dari kuisioner yang sudah dirangkum adalah sebagai berikut:

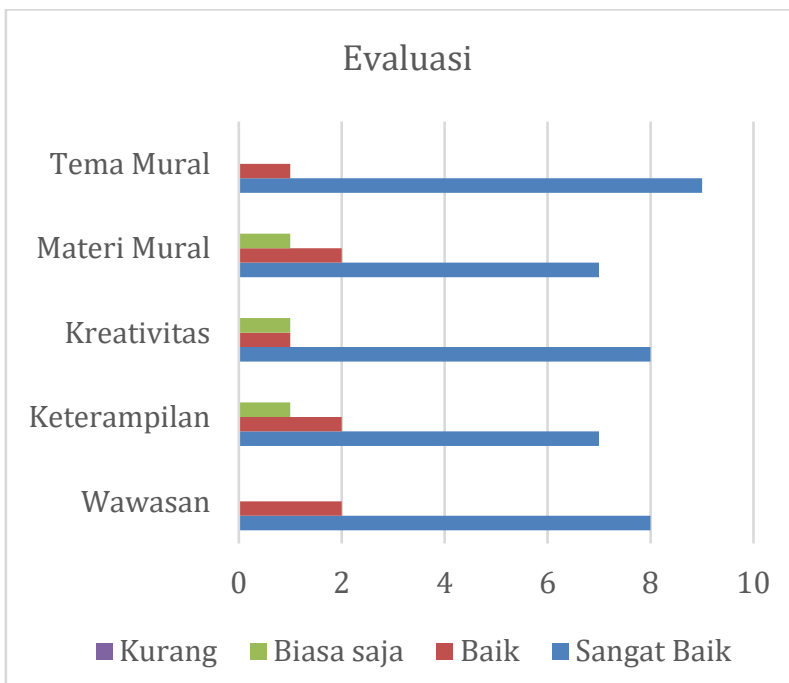

Gambar 10. (Tabel evaluasi sebagai umpan balik kegiatan PKM)

Sumber: Olah data pribadi

Dari pertanyaan pilihan ganda yang diberikan diperoleh hasil sebagain besar peserta bertambah wawasan, keterampilan dan kreativitas pada kegiatan ini, sehingga para peserta sangat tertarik dan antusias untuk mengikuti kegiatan tersebut.

Dari pertanyaan uraian yang diberikan mengenai kritik dan saran pada kegiatan pembuatan mural, para peserta menilai kegiatan ini sangat positif dan berharap dengan adanya tampilan visual baru pada sekolah, para guru dan murid semakin semangat dalam belajar sehingga dapat menciptakan prestasi yang baik untuk mengenalkan sekolah kepada masyarakat, sehingga semakin banyak murid yang tertarik pada sekolah ini.

Dengan adanya umpan balik yang positif pada kegiatan ini, potensi keberlanjutan kegiatan pembuatan mural ini bisa dilakukan pada lokasi yang lain dengan konsep atau tema yang berbeda sehingga semakin banyak masyarakat yang mendapat edukasi dan keterampilan dalam memperbaiki visual bangunan.

\section{KESIMPULAN}

Proses kegiatan dilakukan oleh beberapa dosen sebagai tim pengabdian dengan melibatkan mahasiswa agar ilmu dan pengetahuan dapat diaplikasikan langsung ke masyarakat. Kegiatan pengabdian kepada masyarakat ini juga sebagai bentuk aktivitas dosen dalam menerapkan nilai-nilai ilmu pengetahuan yang sudah didapat. Pengabdian masyarakat berupa pembuatan mural disekolah ini terlaksana dengan baik sesuai dengan yang telah direncanakan.

Dari hasil sosialisasi sampai dengan proses pengerjaan para peserta PKM sangat antusias dan sangat senang bisa mempelajari cara-cara dalam pembuatan mural, dimana peserta mendapat keterampilan baru yang belum pernah diperoleh sebelumnya sebagai bekal dalam membuat suatu inovasi juga memberi warna baru pada tampilan visual sekolah sehingga membuat semangat dalam proses belajar mengajar. Hal ini dilihat dari hasil evaluasi berupa umpan balik kepada peserta kegiatan pengabdian pembuatan mural edukasi. Dampak positif bagi tampilan visual yang baik ini menambah kesan yang terlihat lebih indah dan ceria, selain itu dampak dari aspek psikologi diharapkan dapat menambah minat belajar serta minat mengajar guruguru semakin meningkat dan proses edukasi dalam bentuk mural ini bisa dimanfaat untuk pengetahuan.

\section{UCAPAN TERIMAKASIH}

Ucapan terimakasih disampaikan kepada Lembaga Penelitian dan Pengabdian Masyarakat (LPPM) UNIMED pada program PKM PNBP 2020, yang sangat mendukung program pengabdian ini berlangsung dengan baik. Serta dukungan dari Jurusan Pendidikan Teknik Bangunan Fakultas Teknik dan Fakultas Seni Univesitas Negeri Medan. Kepada Sekolah SDI Ar-ridha yang sudah bersedia menjadi mitra kegiatan pengabdian kepada masyarakat.

Teknologi Informasi dan Komunikasi 


\section{REFERENSI}

Chotib, Sjahidul Haq, 2012, Kajian Seni Mural/ Graffity sebagai media informasi dan sosialisasi program sekolah yang peduli dan ber-wawasan lingkungan, Madinah, 8(2), 111.

Harani, A. R., \& Motic, K. (2017). Pengaruh Fasade Bangunan Terhadap Karakter Visual Kawasan (Studi Kasus : Pecinan Semarang, Malaysia dan Singapura). Jurnal Pengembangan Kota, 1-8.

Nababan, R.S., (2019). Karya Mural Sebagai Medium Mengkritisi Perkembangan Jaman (Studi Kasus Seni Mural Karya Young Surakarta) Proceeding: International Conference on Art, Design, Education, and Cultural Studies (ICADECS)

Ramadani, F. R., \& Sabiruddin, H. (2018). Peran Sosial Dalam Seni Mural di Kota Samarinda. e-Jurnal Ilmu Komunikasi UNMUL.
Thamrin, N. H., \& Noviana, M. (2020). Pendampingan Pembuatan Mural Sebagai Upaya Perbaikan Visual Kawasan Loa Buah, Samarinda Kota Samarinda, Aksiologiya: Jurnal Pengabdian Kepada Masyarakat 4(1), 91-99.

Wahyudi, A. T., Natadjaja, L., Wicandra, O. B., Waluyanto, H. D., (2017). Kajian Partisipasi Masyarakat dalam Kegiatan Mural (Studi Kasus : Mural Dinding Sekolah TK YBPK Sekar Indah Malang),NIRMANA,17(2),87-95.

https://doi.org/10.9744/nirmana.17.2.87-95

Yusuf, A. W., (2014). Partisipasi masyarakat dalam pembangunan kota yang berkelanjutan dan berkeadilan, Administrasi Publik, 11(2), 58. 